\title{
COMER VIAJANTE: UMA INCURSÃO PELA ALIMENTAÇÃO EM DIFERENTES PAÍSES
}

\author{
Constance Oderich ${ }^{1}$ \\ Eliziane Nicolodi Francescato Ruiz ${ }^{2}$
}

\section{Uma introdução sobre o comer viajante}

A alimentação está muito além de ser apenas algo vital para o ser humano, pois nossas escolhas alimentares não atentam apenas para a obtenção de nutrientes. Dentro de um universo de grande variedade alimentar, são diversas as variáveis que falam de pertencimento e identidades, transbordando significados:

Dize-me o que comes e te direi qual Deus adoras, sob qual latitude vives, de qual cultura nasceste e em qual grupo social te incluis. A leitura da cozinha é uma fabulosa viagem na consciência que as sociedades têm delas mesmas, na visão que elas têm de sua identidade (Bessis, 1995: 10).

Dessa forma, entendemos que a comida, a maneira de prepará-la, a forma e lugar de servi-la, os momentos de compartilhá-la, são capazes de informar sobre as pessoas, falar de identidades, cotidianos, valores, diferenças. A alimentação, assim, assume um comunicado, a partir do qual um grupo social expressa seu mundo. $\mathrm{O}$ estudo emerge da necessidade de apreender a alimentação a partir de outras dimensões que pudessem se somar à dimensão biológica tão tradicional na ciência da Nutrição da qual nos originamos. Do campo da saúde, através de uma incursão etnográfica, se desperta para os referenciais da antropologia e amplia-se a compreensão dos sentidos da alimentação em diferentes culturas, no intuito de conhecer mais da sua própria.

O ser viajante, e o ato de comer aqui tracejado, abraça as mudanças pessoais e individuais na alimentação durante a viagem, mas é fundamentado, especialmente, no comer compartilhado e no ato de comer do outro. Ao comer em companhia, as partes envolvidas estão compartilhando as mesmas sensações, seus costumes, valores, podendo reforçar a afinidade e semelhanças entre as mesmas e assim intensificar a coesão de um grupo (Maciel, 2001). A comida compartilhada propicia momentos de

\footnotetext{
${ }^{1}$ UFRGS, Brasil. Email: con.oderich@hotmail.com ORCID id: http://orcid.org/0000-0002-9133-8933

${ }^{2}$ UFRGS, Brasil. Email: elizianeruiz@yahoo.com.br ORCID id: $\underline{\text { http://orcid.org/0000-0002-8632-6612 }}$
} 
interação, sendo um ato carregado de forte conteúdo social e de grande poder de comunicação (Flandrin; Montanari, 2015).

Acerca das circunstâncias do viajante, viajar significa expor-se, arriscar-se à alteridade, à novidade, ao estrangeiro, ao incomum e ao incomensurável (Michel, 2000). Em um processo de desenraizamento, o viajante é alguém não portador de identidade, é alguém que está disposto a viver como a outra cultura (Peixoto, 1987). Assim, enxergase essa inserção do viajante em outra cultura, e a paralela análise da mesma como uma atividade de "antropologia ao ar livre" (Laplantine, 2003), ou até mesmo de viajante pesquisador, nos termos desta pesquisa.

$\mathrm{Na}$ posição de viajante, mais do que colocar-se no lugar do outro, buscamos seguir o princípio ético da alteridade descrito por Geertz (2001), convivendo sendo quem se é, sem julgamentos e respeitando a existência de diferenças culturais. Ao nos inserirmos em outra cultura, fazendo o exercício da alteridade, sensações de inquietação e estranhamento manifestaram-se especialmente no enfoque da comida, gerando curiosidade e interesse pela exploração de outras culturas e da nossa própria (Laplatine, 2003). Nas palavras do autor,

presos a uma única cultura somos não apenas cegos à dos outros, mas míopes quando se trata da nossa. A experiência da alteridade [...] leva-nos a ver aquilo que nem teríamos conseguido imaginar, dada a nossa dificuldade em fixar nossa atenção no que nos é habitual [...] O conhecimento da nossa cultura passa inevitavelmente pelo conhecimento das outras culturas (LAPLATINE, 2003: 12-13).

A partir da exploração do ato de comer compartilhado e agregador, do ser viajante e da problematização da alimentação durante a nossa formação em Nutrição, uma viagem realizada em ritmo humano nos pareceu um cenário ímpar para explorar diferentes culturas alimentares. Nesse sentido, neste estudo tivemos o objetivo de explorar experiências de viagens, especialmente as experiências do comer em diversos lugares, analisando os seus significados nas diferentes sociedades.

\section{Percursos metodológicos}

Este estudo parte de uma viagem realizada por uma das autoras e seu companheiro Mateus. De bicicleta, durante o outono europeu de 2016, foram percorridos mais de três mil quilômetros pela Europa e África. Pedalamos por quase três meses pela França, Espanha, Marrocos e Portugal, passando por vilas remotas de 
grandes metrópoles. Iniciamos a viagem com o percurso e os locais onde iríamos pernoitar não definidos, sendo guiados por mapas e com auxílio de GPS.

Partimos pedalando da cidade de Nantes, região Noroeste da França, em direção ao Leste até chegarmos em Saumur. De lá, embarcamos em um trem para Ventimiglia, pequena cidade italiana na Costa Mediterrânea localizada na fronteira com a França. De bicicleta, cruzamos a aduana francesa e percorremos todo o litoral mediterrâneo francês até Barcelona, de onde embarcamos em um ferry boat para o Marrocos. Do porto de Tanger Med pedalamos em direção ao Sul marroquino por 10 dias, voltando para a Espanha. Desembarcando em Gibraltar, tomamos um ônibus para Sevilha, de onde pedalamos rumo ao Oeste, cruzando a aduana portuguesa e chegando ao ponto mais Sudoeste da Europa, Sagres. Por fim, pedalamos na costa litorânea portuguesa rumo ao Norte, cessando a viagem em Lisboa.

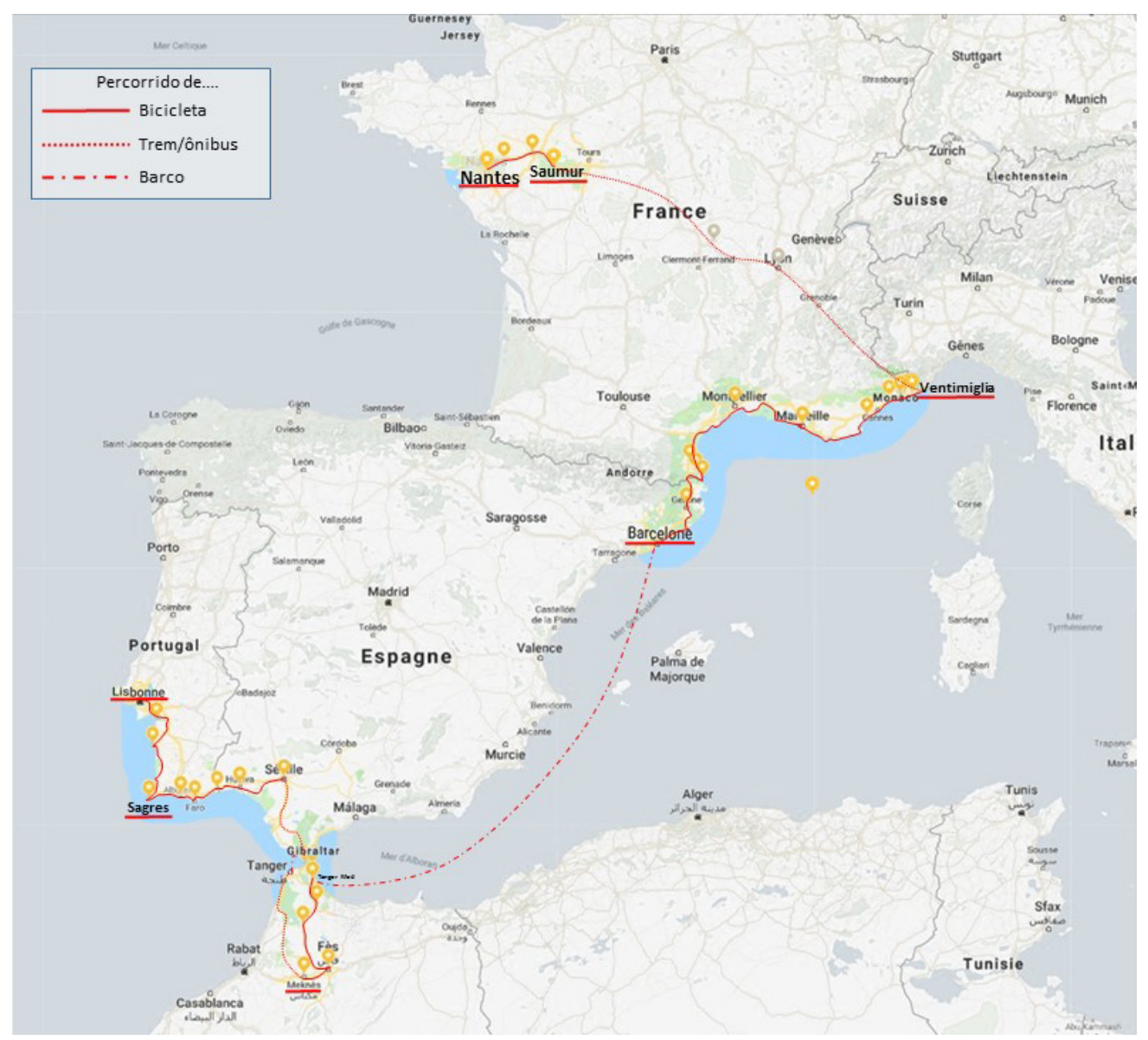

Figura 1. Mapa do trajeto percorrido.

Fonte: Google Maps (https://maps.google.com.br) (2016). 
Diariamente, tínhamos contato com moradores locais e ciclistas que cruzavam nosso caminho, e essas interações foram fundamentais para a construção da viagem. A participação dessas pessoas foi muito além de dicas sobre rotas e conversas descontraídas. O interesse e a empatia das pessoas com o cicloviajante nos propiciou inúmeras vivências com desconhecidos.

Pernoitamos em casas de ciclistas que conhecemos pela internet através da plataforma Warmshowers (rede de hospedagem gratuita para cicloviajantes e simpatizantes), casas de moradores que nos abordaram e se ofereceram para nos acolher e em pátios de casas, nas quais solicitamos ao dono um espaço para acampar. Ficamos em hotéis e albergues apenas no Marrocos. Quando os anfitriões nos recebiam, sempre com euforia, nos orientavam sobre a acomodação e nos chamavam para participar dos afazeres na cozinha pré e pós-jantar e café da manhã.

A comensalidade, ao receber visitantes, é pré-histórica, data das primeiras civilizações. A primeira forma de hospitalidade, de acordo com Peyer (2015), refere-se à acolhida amigável, quando, sem a necessidade de pagamento, oferecia-se abrigo e refeição ao viajante, favorecendo a ligação íntima entre anfitrião e hóspede. Ao longo de nossa viagem, desfrutamos de inúmeras acolhidas amigáveis. Os momentos de sociabilidade foram recíprocos tanto para os anfitriões quanto para nós, e esse era o pagamento. Além de estarmos partilhando o mesmo alimento e abrigo, estávamos fazendo trocas e tecendo elos, e o cansaço e a barreira do idioma estrangeiro não foram empecilhos para que isso acontecesse.

Rotineiramente, escrevíamos sobre as vivências compartilhadas com anfitriões e sobre percepções originadas a partir do estranhamento da cultura do outro. Esses diários de campo, juntamente com os registros fotográficos, tornaram-se produtos/ferramenta/objeto de estudo a serem analisados, aqui, de forma qualitativa. Assim, expostos à alteridade na posição de viajantes, ancoramos este estudo a partir dos processos de estranhamentos vivenciados à mesa de culturas distintas da Europa e África. Para tanto, buscamos explorar e apreender os significados e valores dessas diferentes culturas alimentares através do dialogo entre a experiência viajante e o referencial da socioantropologia da alimentação. 
A rotina alimentar do cicloviajante e a centralidade da comida: comer e (sobre)viver

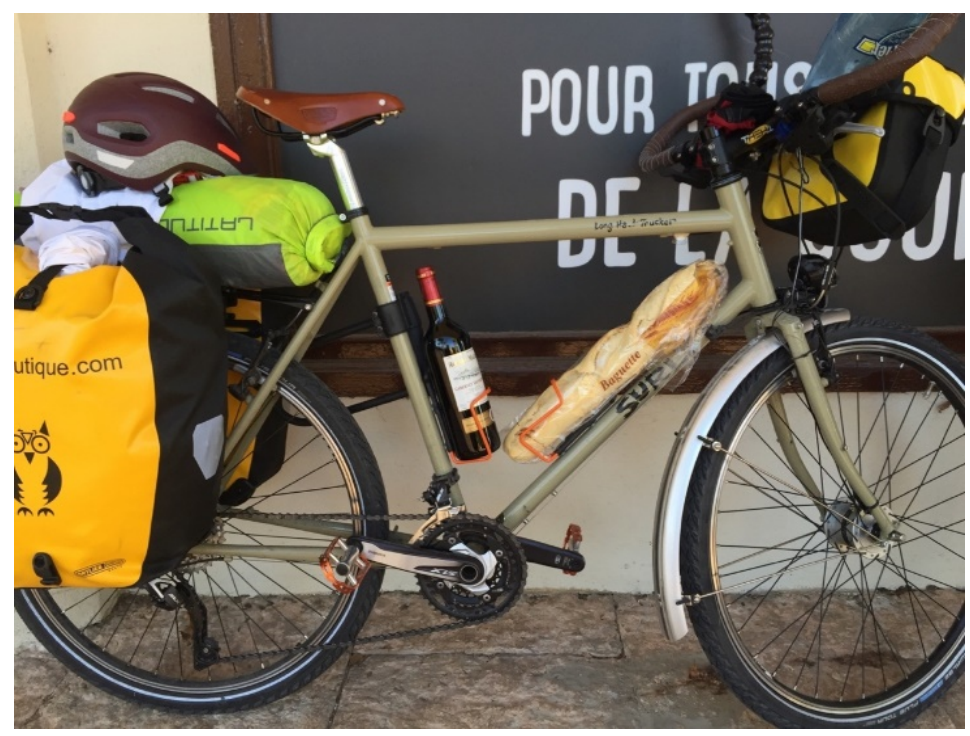

Figura 2. Bicicleta carregada com alforjes, barraca, vinho e baguete.

Fonte: Acervo pessoal (2016).

Durante a viagem, raramente sabíamos onde iríamos comer e pernoitar. No entanto, equipados com barraca, fogareiro, panelas e alimentos para cozinhar, tínhamos autonomia para escolher onde repousar. Ao escurecer, iniciávamos a busca por um lugar público que fosse seguro, escondido e confortável para montar a barraca. Muitas vezes nos instalávamos em meio à mata, a poucos metros da estrada.

Quando acampávamos, tínhamos o hábito de cozinhar. O que cozinhávamos, naturalmente, dependia da localidade e do que havia disponível nela. Na Europa, frequentávamos supermercados e padarias para comprar os insumos das refeições. No horário do almoço, parávamos em algum lugar em meio à natureza para preparar o que costumávamos almoçar: um sanduíche de baguete, queijos variados e salada. Para o jantar tínhamos o hábito de cozinhar massa com legumes e molhos variados, couscous e lentilha.

No Marrocos, nossos hábitos alimentares mudaram bastante devido ao que havia disponível nas pequenas vilas por onde passávamos. Diferente do que ocorrera nos países europeus, no Marrocos não tínhamos uma rotina alimentar e não conseguíamos planejar nossas próximas refeições. Migramos de um cenário com abundância de oferta de alimentos e de um variado consumo de hortaliças e queijos para um cenário com limitada oferta e escolha alimentar. Passamos por muitas regiões marroquinas pouco 
habitadas, percorrendo grandes distâncias sem alimentos disponíveis. Com esse cenário, somado à grande valorização da moeda estrangeira, acabamos sempre comprando nossas refeições prontas ou comendo em pequenos restaurantes. Ainda, enquanto na Europa evitávamos o consumo de carne por questões morais, sociais e ambientais, no Marrocos era quase inevitável não comermos carnes todos os dias no almoço e jantar devido às escassas opções.

$\mathrm{Na}$ sociedade de consumo, muitos fatores são considerados indicadores da individualidade do gosto e do senso de estilo do proprietário/consumidor (Featherstone, 1995). Assim, entretenimentos de lazer, preferências de comida e bebida, opção de férias, roupas e outros fatores, podem dizer muito sobre um indivíduo. Nós éramos um casal brasileiro que estava viajando de bicicleta pelo Continente Europeu e que acampava habitualmente. Esse contexto dizia muito sobre nós e, claramente, percebíamos como outros ciclistas com os quais convivemos no decorrer da viagem possuíam, muitas vezes, os mesmos estilos, gostos alimentares e preocupações.

Assim, frequentemente, quando éramos recebidos na casa de ciclistas, eles nos perguntavam se comíamos carne, derivados de leite ou se tínhamos alguma aversão alimentar. E, nessas casas, nas refeições que nos eram oferecidas havia grande variedade de frutas, legumes, saladas e alimentos integrais, muito próximos dos nossos. Para Maciel, "mais que alimentar-se conforme o meio a que pertence, o homem se alimenta de acordo com a sociedade a que pertence e, ainda mais precisamente, ao grupo, estabelecendo distinções e marcando fronteiras precisas” (Maciel, 2001: 149).

Durante a viagem, a comida aparece como elemento central, não sendo importante apenas para a sobrevivência. Acampamos e cozinhamos muito, mas em grande parte da viagem comemos em casa de ciclistas e de outros moradores locais. No dia em que partiríamos de Nantes para iniciar a viagem, fomos convidados por um amigo ciclista para um petit déjeuner des voyageurs (café da manhã dos viajantes) em sua casa. Desfrutamos de um café da manhã clássico, com frutas, baguete, manteiga e mel. Já na estrada, durante a tarde do mesmo dia, outro ciclista nos abordou e ofereceu um lanche em sua casa para conversarmos. Em ambas as situações os ciclistas reforçaram ser essencial carregarmos doces (chocolate, mel ou tâmaras) para sempre termos energia.

Desde o início da viagem percebemos que, pela cultura viajante dos ciclistas, a comida seria um grande elo socializador e, provavelmente, o doce estaria presente. A 
comida foi um gatilho para a socialização e para interpretar diferentes lugares e pessoas, uma espécie de lente para analisar diferentes contextos e modos de vida de diferentes grupos. Portanto, nessa incursão, consideramos a comida elemento central, como cultura:

Comida é cultura quando consumida, porque o homem, embora podendo comer de tudo, $[. .$.$] na verdade não come qualquer coisa, mas escolhe a própria comida, com$ critérios ligados tanto às dimensões econômicas e nutricionais do gesto quanto aos valores simbólicos de que a própria comida se reveste (Montanari, 2008: 15-16)

\section{A pizza — símbolo da homogeneização alimentar}

$\mathrm{Na}$ França, chegamos à noite ao apartamento da nossa primeira experiência com o Warmshowers. Nossa anfitriã nos recebeu com um largo sorriso, dizendo que a mesa já estava posta, que nos acomodássemos no quarto e em seguida iríamos jantar. Para nossa surpresa, e apesar da culinária francesa ser referência em gastronomia, o prato servido foi pizza. A escolha da pizza foi justificada pela anfitriã: "por ser uma comida internacional que todo mundo gosta".

Por que a pizza, um dos símbolos da cozinha italiana, é considerada uma comida internacional? A alimentação, gradualmente, homogeneizou-se (Fischler, 1995). Na esfera da alimentação, na contemporaneidade, podemos analisar dois processos presentes com tendência à homogeneização: a globalização e a mundialização (Ortigoza, 2001). O primeiro, embora possua distintos significados, engloba o crescimento de investimentos, produção, comércio e redes de informática, possuindo um peso na economia, na produção e no mercado. Já o segundo processo, a mundialização, envolve os aspectos modos de vida, comportamentos, culturas e consumos.

Entretanto, na percepção de Poulain (2004), ao mesmo tempo em que esses processos nivelam certas diferenças, são também o motor de um processo de diversificação-integração, pois implicam novas diferenciações alimentares e criação de espaços em comum entre culturas. Isso ocorre porque, com a mundialização dos mercados e a mestiçagem de populações (tanto pelas migrações quanto pelo desenvolvimento do turismo internacional), há uma troca de produtos e técnicas culinárias. Assim, a apropriação de produtos ou de técnicas de preparo de alimentos de outras culturas contribui para o surgimento de novas variações alimentares e o desenvolvimento de espaços comuns que servem de ponte entre os modelos alimentares. 
Dessa forma, alimentos que aparecem nesses espaços intermediários comuns são considerados produtos transculturais, como é o caso do hambúrguer e da pizza (Poulain, 2004). Assim, por mais que a pizza seja um símbolo da culinária italiana, ela representa um elo entre diferentes modelos alimentares. E foi o que percebemos naquela noite, no apartamento de nossa anfitriã.

Quando acabamos de jantar, nossa anfitriã disse que ia nos deixar à vontade no apartamento, pois atualmente estava morando com seus pais. Ficamos surpresos e felizes com a hospitalidade, aceitamos o convite e a convidamos para jantar conosco na noite seguinte.

\section{Cozinhando para uma francesa: o que mostrar da nossa cozinha?}

Queríamos cozinhar algo com identidade brasileira, mas como precisávamos encontrar os ingredientes em um supermercado francês, nossas opções estavam limitadas. Por fim, escolhemos uma preparação com carne de frango devido ao preço elevado da carne vermelha na França. Comida à mesa, fiz questão de servi-la: salada de alface e tomate temperada com azeite de oliva, arroz integral, estrogonofe de frango e batata chips.

Durante o jantar, após elogiar a comida, nossa anfitriã falou que achou muito interessante comermos tudo no mesmo prato, todos os alimentos servidos de uma vez só, fazendo uma comparação ao tradicional Menu Français: ter entrée, plat principal, fromage, dessert. Nós sabíamos da tradicional sequência francesa, mas não havia me dado conta no momento em que a servi. Explicamos para ela que não temos esse ritual e que as preparações são servidas simultaneamente, ficando postas à mesa (geralmente nas próprias panelas) para repetirmos quantas vezes quisermos. A lógica e o ritual de ingestão dos alimentos são aspectos distintos entre as culturas alimentares.

No artigo Feijão com arroz e arroz com feijão: o Brasil no prato dos brasileiros (Barbosa, 2007), a autora classifica algumas características que aparecem no momento de combinar alimentos, nas lógicas de ingestão da comida, nas técnicas de cocção e nas maneiras à mesa como "específicas" do comer brasileiro. Em nosso sistema de refeições, vigora o "junto, mas separado", em que, em um mesmo prato, servem-se diferentes tipos de comida, mantendo-os separados em pequenos montes (Barbosa, 2007). 
Outra característica que difere o comer brasileiro e, desse modo, os nossos costumes, é a informalidade à mesa e a apresentação da preparação, pois é muito comum que as preparações sejam postas à mesa dentro das próprias panelas em que foram cozidas. Essa despreocupação com a apresentação da comida também se reflete na apresentação dos pratos, em que a aparência deles é pouco valorizada como determinante de comida boa (Barbosa, 2007).

Retornando ao jantar servido a nossa anfitriã, escolhemos preparar uma pizza de chocolate ao leite com queijo emmental (queijo de sabor suave comum na França) como sobremesa, justamente por saber que os europeus não são acostumados com pizza doce e, muito menos, com a mistura de queijo com doce. Naturalmente, a sobremesa causou estranheza à anfitriã.

Resgatando a abordagem da mundialização e globalização, embora os dois processos tragam uma tendência de homogeneização de gosto e costumes, a apropriação de produtos e técnicas de preparo de alimentos de outras culturas possibilita criar novas preparações alimentares, resultando em formas originais de apropriação de produtos ou técnicas (Poulain, 2004). Com a "internacionalização" da pizza, é possível comprar uma massa pronta da mesma em supermercados de, praticamente, qualquer lugar do mundo e adaptar o recheio de acordo com a preferência do gosto de quem a cozinha. A pizza de chocolate com queijo é a apropriação de um alimento típico italiano, mas original na gastronomia brasileira.

Cada cultura possui uma cozinha peculiar, com diferentes ingredientes, aromas, técnicas de preparo, combinação de alimentos e maneiras de servir e comer. Na cozinha francesa, o salgado e o doce se excluem mutuamente, enquanto que em outras culturas o agridoce é muito comum (Contreras; Gracia, 2011). Entretanto, uma vez expostos a novos alimentos e misturas, podemos degustá-los e agregá-los ou não ao nosso leque de possibilidades de preparação.

\section{A resistência francesa: o valor da comensalidade, a comida como patrimônio e a identidade que se conserva}

Seguindo a linha da alimentação como facilitadora da inclusão social, é nas as práticas alimentares à mesa, afirma Poulain (2004), que se tecem e se mantêm os vínculos sociais, além de ser um momento em que é possível transmitir e permitir a 
interiorização dos valores de um grupo. Assim, compartilhando refeições com os franceses, ficou muito evidente o quanto eles valorizam os momentos à mesa e todo o ritual da alimentação na cozinha. Em sua obra Comer: a alimentação de franceses, outros europeus e americanos, Fischler (2010) evidencia a importância para os franceses sobre a partilha do alimento e a sociabilidade, tanto em casa quanto fora dela. Em uma das entrevistas da obra, quando o autor perguntou o que significava "comer bem" para um participante francês, percebemos que a convivialidade é um caráter de necessidade tão imperativo quanto o equilíbrio nutricional:

Significa fazer uma refeição simples, entre amigos, em frente a uma travessa de frutos do mar. Significa comer um prato tradicional: por exemplo, um cozido com legumes, em família; ir a um bom restaurante de vez em quando (mulher, operária, 50 anos) (Fischler; Masson, 2010: 53).

Os franceses citam o prazer como uma dimensão inerente ao "comer bem", e quando esse prazer é vivido em comum ele é o mais valorizado, devendo satisfazer uma exigência importante, a da partilha e da socialização. Assim, Fischler (2010) resume as características da alimentação francesa em duas palavras-chave: prazer e convivialidade.

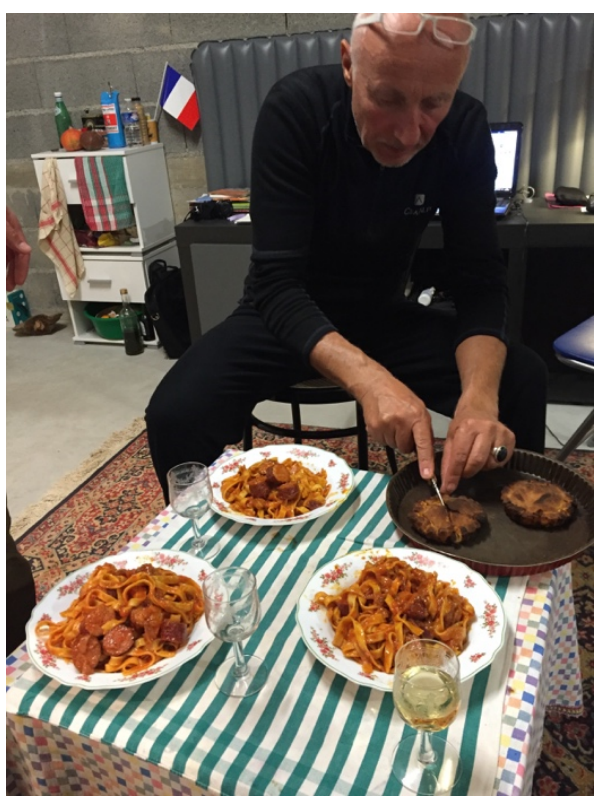

Figura 3. Comensalidade francesa desde o preparo até a partilha da comida típica.

Fonte: Acervo pessoal (2016). 
Retomando a homogeneização alimentar oriunda da globalização e da mundialização, é possível partir da premissa de que a globalização pode tanto dividir quanto unir. Com a perda de identidade e o abandono de tradições e pratos, dado que as cozinhas estão se igualando progressivamente, a gradativa homogeneização alimentar que ocorre no tempo presente provoca uma nostalgia em relação aos modos de se alimentar, à cozinha tradicional e a outras particularidades e diversidades que agora pertencem ao passado, havendo uma revalorização dos mesmos. Assim, começamos a falar sobre patrimônio, termo que, de acordo com Contreras, relaciona-se a algo que nos foi legado pelo passado e que desejamos conservar (Contreras, 2005: 129).

Os mesmos processos que levam à homogeneização cultural e alimentar podem também atuar como forças de articulação de resistências, movimentos de afirmação de identidade, que, contrariamente ao que é esperado, faz com que se recupere uma variedade de pratos típicos locais, havendo a revalorização dos sabores e costumes tradicionais.

Converter o que é próprio em patrimônio significa perpetuar a transmissão de uma particularidade ou de uma especificidade considerada própria e portanto identificada, isto é, permite que um coletivo determinado possa continuar vivo - de um lado, idêntico a si próprio, e de outro, distinto dos demais (Contreras, 2005: 130).

Assim, considerando que não são somente os aspectos físicos que constituem a cultura de um povo, mas sim aspectos contidos nas tradições, nos saberes, nas línguas, nas festas e em diversos outros aspectos e manifestações, a Unesco nomeou essa porção imaterial da herança cultural dos povos como Patrimônio Cultural Imaterial. Esse Patrimônio é composto por práticas, representações, expressões, conhecimentos e técnicas - junto com os instrumentos, objetos, artefatos e lugares que lhes são associados - que as comunidades, os grupos e, em alguns casos, os indivíduos reconhecem como parte integrante de seu patrimônio cultural. Esse patrimônio que se transmite de geração em geração é, constantemente, recriado pelas comunidades em função de seu ambiente, de sua interação com a natureza e de sua história, gerando um sentimento de identidade, contribuindo para a promoção do respeito à diversidade cultural e à criatividade humana (UNESCO, 2003).

A fim de serem preservadas, algumas culinárias já são reconhecidas como patrimônio e encontram-se na Lista Representativa do Patrimônio Cultural Imaterial da Humanidade (UNESCO). A primeira culinária a entrar para a lista foi a gastronomia francesa, em 2010. 
Considerando algumas passagens descritas neste texto e tantas outras vividas na França, país onde passamos metade da viagem e com a cultura que mais tivemos oportunidades de conviver, é visível a grande resistência dos costumes da culinária francesa, desde seus rituais até a escolha e cuidado do que comer. No documento que confere a inscrição da gastronomia francesa para a lista de patrimônio cultural, ela é descrita da seguinte forma:

\begin{abstract}
A refeição gastronômica francesa enfatiza a união, o prazer do paladar e o equilíbrio entre o homem e os produtos da natureza. Elementos importantes incluem a seleção cuidadosa de pratos [...]; a compra de produtos bons, preferencialmente locais, cujos sabores combinam bem; o emparelhamento de comida com vinho; a colocação de uma linda mesa [...]. Deve respeitar uma estrutura fixa, começando com um apéritif (bebidas antes da refeição) e terminando com licores, contendo entre pelo menos quatro pratos sucessivos, nomeadamente uma entrada, peixe e/ou carne com legumes, queijo e sobremesa [...] A refeição gastronômica francesa aproxima círculos de familiares e amigos e, de maneira mais geral, fortalece os laços sociais (UNESCO, 2010).
\end{abstract}

Afirmando o enraizamento da gastronomia francesa com a sua cultura, na pesquisa de Fischler (2010), sobre o Comer ao redor do mundo, os participantes foram estimulados a escolher uma metáfora que ilustrasse a relação daquele que come com o alimento. As opções de metáforas eram: árvore, indústria, templo e carro, estando cada uma associada a diferentes campos simbólicos. Como resultado, árvore foi escolhida por $63 \%$ dos franceses. O pesquisador relaciona essa preferência à afinidade dos franceses com a natureza e com o enraizamento de costumes:

[...] a metáfora da árvore remete à natureza, mas também à identidade local, ao ancoradouro, ou ao arraigamento em um território e uma cultura, bem como ao equilíbrio entre o homem e o meio ambiente. (Fischler; Masson, 2010: 115)

Algumas percepções dos franceses sobre a alimentação contemporânea também foram identificadas por Fischler (2010). A maioria dos franceses concorda que os alimentos da atualidade possuem um sabor pior do que os do passado e que os alimentos e hábitos alimentares de hoje são menos sadios do que os de antigamente. $\mathrm{Na}$ mesma pesquisa, o autor quis saber dos participantes o grau de concordância sobre algumas afirmações relativas à alimentação. Em relação à afirmativa "basear-se nas tradições é o melhor meio de ter uma boa alimentação", mais da metade dos franceses entrevistados concordaram, dizendo que para ter uma alimentação sadia, as tradições surgem como o melhor meio para atingir esse objetivo (Fischler; Masson, 2010).

Desse modo, a alimentação, a culinária e a refeição são atividades positivas, valorizadas, que os franceses desejam proteger contra o que concebem como uma 
degradação trazida pela modernidade (Fischler; Masson, 2010). Nas palavras de Poulain (2004, p. 38), "a história da alimentação mostrou que cada vez que identidades locais são postas em perigo, a cozinha e as maneiras à mesa são os lugares privilegiados de resistência”. Assim, os patrimônios podem ser considerados os novos recursos da modernidade (Contreras, 2005) porque, ante a globalização, movimentos de resistência cultural e indenitária valorizam a gastronomia como patrimônio, fugindo da uniformização cultural.

\section{O pagamento da conta do restaurante: reciprocidade e vínculos}

Poucas vezes partilhávamos da sociabilidade alimentar em um restaurante. Em determinada situação, entramos em um, em companhia de um ciclista que havíamos acabado de conhecer, o Pierre. Após o longo e descontraído almoço, assim que o garçom trouxe a conta nos prontificamos a pagar a nossa parte. Entretanto, Pierre fez questão de pagar a totalidade do valor, negando-se a aceitar a nossa contribuição.

Claude Fischler (2010), em sua obra intitulada Comer: a alimentação de franceses, outros europeus e americanos, também cita a situação da partilha de uma refeição em um restaurante e o pagamento da conta. $\mathrm{O}$ autor aponta três soluções para o momento de pagar a conta: uma pessoa paga por todos; divide-se a conta pelo número de convivas ou cada um paga por aquilo que consumiu.

A partir do exposto, Fischler faz uma reflexão sobre cada solução: a primeira representa um caráter mais individualista; as outras duas levam em conta a ocasião e a experiência social, o momento compartilhado. Dividir a conta pelo número de convivas, mesmo que nem todos tenham consumido a mesma coisa, indica, de certa forma, que o que se paga, naquele momento, é o fato de estar entre amigos, compartilhando uma experiência.

A solução de um dos convivas pagar a conta de todos pode significar tanto razões de prestígio ou de preeminência quanto de reciprocidade entre os convivas, uma condição explícita ou implícita de "na próxima eu pago". Tanto nessa ocasião do restaurante quanto em outras, durante a viagem, era evidente a reciprocidade existente na comunidade de ciclistas. Percebíamos uma sociabilidade perpetuando-se através do tempo, mostrando a existência de uma corrente de cooperação, havendo uma reciprocidade futura ou "em dívida" com qualquer ciclista. Em outra oportunidade, nós poderíamos retribuir esse almoço a outro cicloviajante. 


\section{Em terras mediterrâneas: a alimentação saudável em suas diferentes faces}

Chegando à Côte d'Azur (Riviera Francesa), logo percebemos uma grande diferença na oferta de alimentos no supermercado, principalmente pela grande oferta de frutos do mar. Na casa de um dos nossos anfitriões, compramos, ajudamos a preparar e comemos ostras em três diferentes espacialidades: ao vinho, gratinada e com vinagre de figo. Estávamos em terras da cozinha mediterrânea, cujo perfil é considerado modelo de dieta saudável do ponto de vista nutricional e a ser seguido, pois se fundamenta em frutas, hortaliças, grãos integrais, azeite de oliva, oleaginosas, frutos do mar e é escassa em doces e carnes vermelhas (Oldways, 2009).

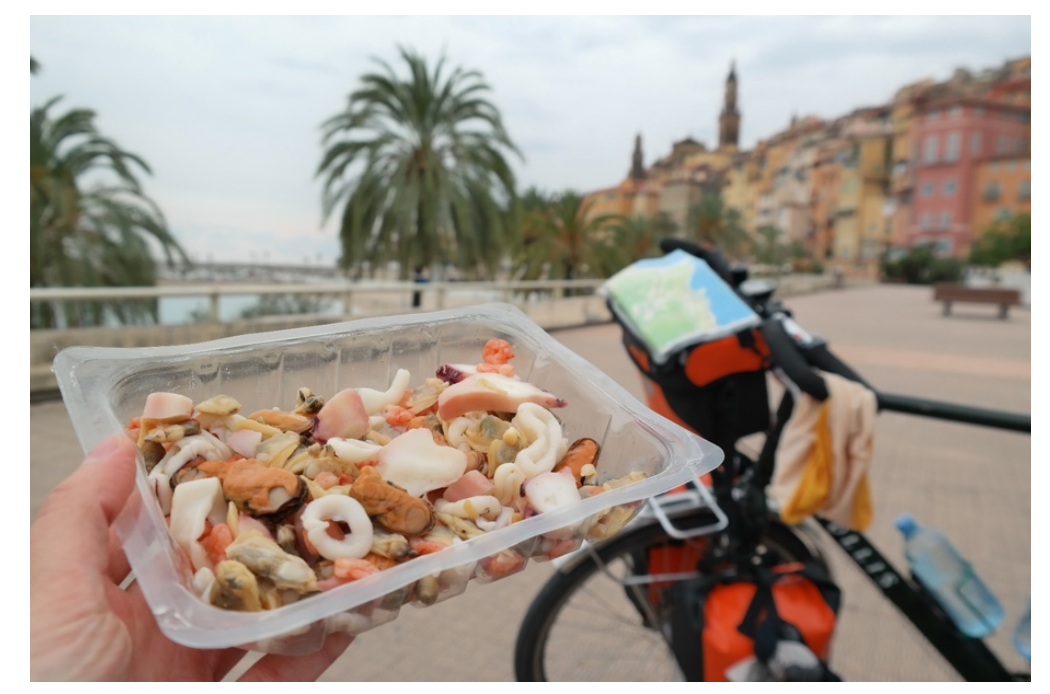

Figura 4. Almoço com frutos do mar comprados em supermercado à beira do Mediterrâneo.

Fonte: Acervo pessoal (2016). 


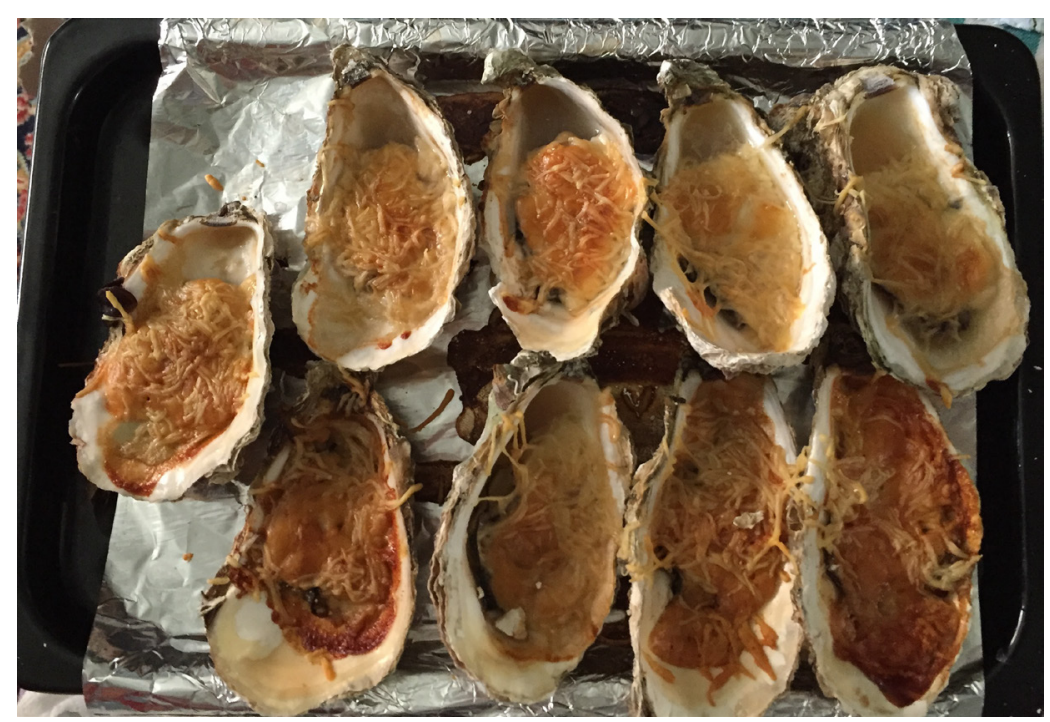

Figura 5. Ostras gratinadas preparadas na casa de um anfitrião francês.

Fonte: Acervo pessoal (2016).

O interesse pela dieta mediterrânea iniciou na década de 1950 devido à constatação de taxas muito baixas de mortalidade por doenças cardíacas e outras não transmissíveis nas regiões ao redor do mar Mediterrâneo, e, até os dias de hoje, continua sendo muito estudada (Canesqui; Garcia, 2005). A dieta mediterrânea, assim como a culinária francesa, também é considerada um Patrimônio Cultural Imaterial da Humanidade (inscrita por Chipre, Croácia, Espanha, Grécia, Itália, Marrocos e Portugal), sendo caracterizada por um

[...] conjunto de habilidades, conhecimentos, rituais, símbolos e tradições referentes a culturas, colheita, pesca, criação de animais, conservação, processamento e, particularmente, o compartilhamento e consumo de alimentos. Comer juntos é a base da identidade cultural e da continuidade das comunidades em toda a bacia do Mediterrâneo [...] Inclui o artesanato e produção de recipientes tradicionais para o transporte, conservação e consumo de alimentos, incluindo pratos e copos de cerâmica (UNESCO, 2013).

A dieta mediterrânea está muito além de ser considerada apenas do ponto de vista nutricional, sendo determinada não somente pela localidade do Mediterrâneo e alimentos disponíveis, mas por toda uma complexa e rica cultura. Unindo as dimensões nutricional e cultural, reflete-se sobre a viabilidade e a real necessidade de transpor modelos de dieta de uma população para outra.

Canesqui e Garcia (2005) abordam duas perspectivas sobre a introdução de um novo modelo alimentar em uma dada cultura. A primeira diz que, independentemente de qual seja a prescrição alimentar, ela será reinterpretada e reintegrada às práticas alimentares empregadas em uma segunda cultura, com valores e organizações 
alimentares distintas. Dessa forma, a prescrição, ao ser ressignificada, sofrerá alterações. Em sua segunda perspectiva, as autoras falam sobre o descaso com o patrimônio cultural alimentar dos povos quando são feitas intervenções nutricionais desse gênero.

Praticamente, na totalidade das vezes, a dieta mediterrânea é reduzida ao consumo de frutas, verduras, pescados e azeite de oliva. Assim, além de ser descontextualizada do meio em que é considerada patrimônio, ela se reduz a nutrientes ou a itens alimentares, desconsiderando tanto o resultado desse rearranjo quanto a sua própria identidade culinária como patrimônio de outra cultura (Canesqui; Garcia, 2005).

Nesse sentido, passamos a nos questionar: por que não abordar uma alimentação saudável voltada às características regionais de cada lugar? Se olharmos para o Brasil, por que não difundir mais as particularidades culturais e seus diferentes contextos, valorizando a culinária local, considerando saberes, ingredientes e preferências/gostos regionais?

Construir um modelo de dieta pautada apenas na racionalidade nutricional, desconsiderando as dimensões socioculturais, reduz a alimentação à relação saúde e doença. A alimentação possui diversas dimensões e referências, sendo muito heterogênea para ser reduzida a números e combinações de nutrientes.

\section{Marrocos e o peso da tradição: um caso particular}

Nossos hábitos alimentares em terras marroquinas mudaram bastante. Além do contraste da limitada variedade dos gêneros alimentícios, com a abundância de carne nas pequenas vilas pelas quais passamos, outros aspectos do comer em um país africano nos causaram estranhamento e foram relevantes. 


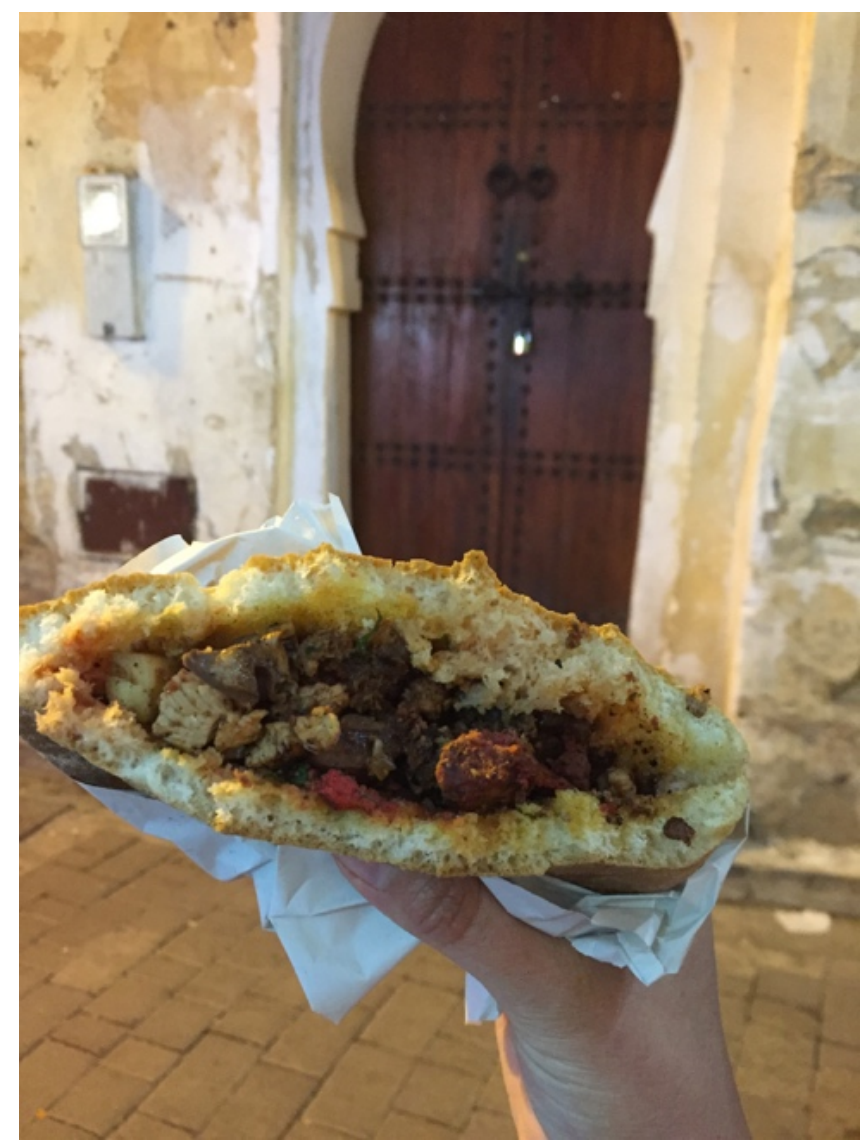

Figura 6. Sanduíche marroquino com carne de cabra.

Fonte: Acervo pessoal (2016).

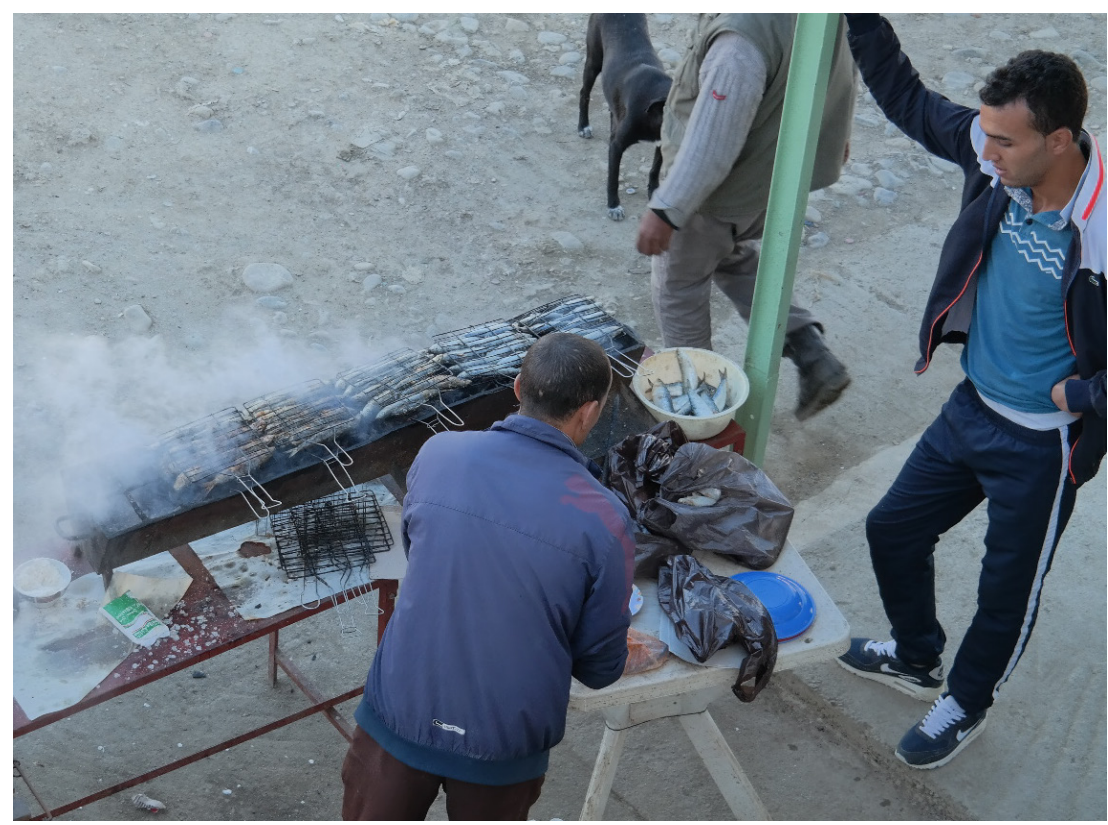

Figura 7. Peixes preparados em churrasqueira à beira da estrada.

Fonte: Acervo pessoal (2016). 
Viajar por diferentes cozinhas étnicas possibilita perceber o sabor e o aroma específico de cada uma. Por mais simples que fossem os lugares onde fazíamos nossas refeições, era comum repousar sobre a mesa uma tigela com muitas especiarias. Cominho, canela, gengibre, cebola, tomate e frutas representam e se destacam no Marrocos. As especiarias representam um importante papel na história do mundo, pois um dos estímulos para que os europeus se lançassem às conquistas dos oceanos e de outros continentes foi a busca pelas mesmas somada à busca por ouro e prata (Flandrin; Montanari, 2015).

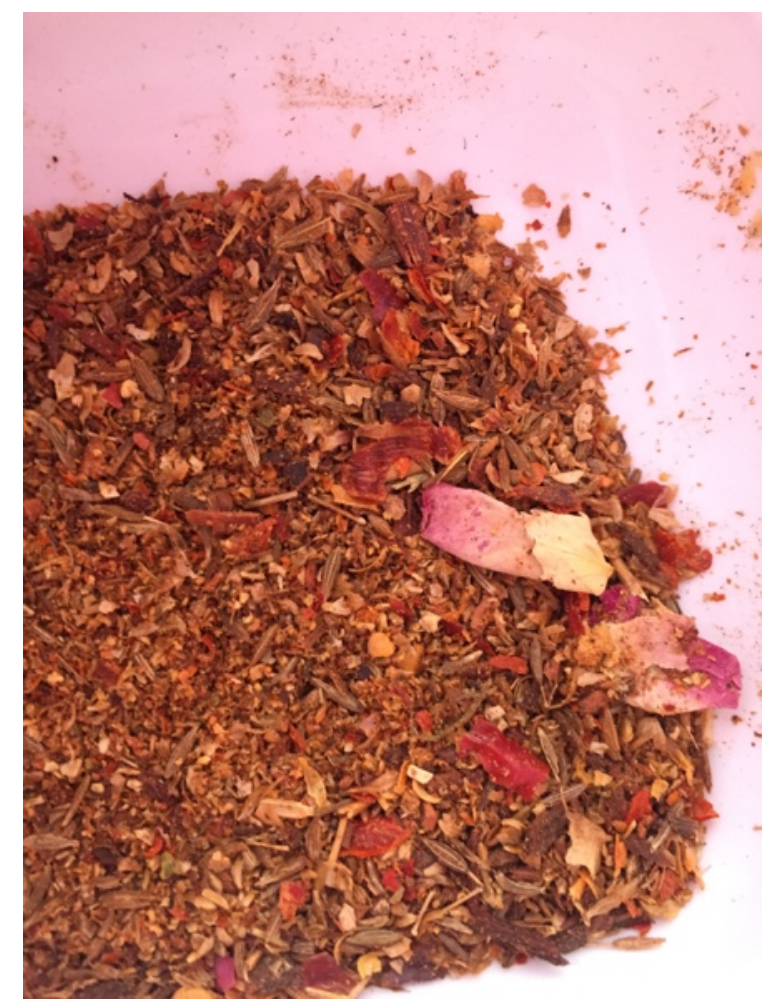

Figura 8. Especiarias oferecidas na mesa de um bar de beira de estrada.

Fonte: Acervo pessoal (2016).

Outro aspecto relevante do comer no Marrocos manifestou-se quando fomos recebidos na casa de um morador do local. A casa era muito simples, sem saneamento básico e com carência de energia elétrica. Logo que nos acomodamos, nosso anfitrião nos serviu um jantar farto, com variedades, e todo o alimento servido fora feito em casa - caseiro: azeitonas, azeite de oliva, pães e tajine (prato típico marroquino) de cabra com maçã, cenoura e batata. 
Além de oportunizar a comunicação entre os convivas, o que é oferecido pelo anfitrião pode sugerir sua posição social. Na concepção de Rodrigues (2012), alimentos e refeições podem ser símbolos de riqueza e distinção entre as camadas sociais. Entretanto, ao dissertar sobre a cozinha árabe, Rosenberger salienta que, por mais pobre e inóspito que seja o meio, "a hospitalidade era a lei do deserto: oferecia-se ao viajante o que se tinha de melhor" (Rosenberger, 2015: 340). Não ficou claro se a tajine foi preparada para nós, mas pela expressão do anfitrião deduzimos que esse prato não fazia parte do cotidiano. Maciel (2001), ao refletir sobre o tema, declara que nem sempre o que é considerado típico está presente na rotina alimentar, tanto por motivos econômicos - quando se limita o consumo de certos alimentos devido à renda quanto pelo próprio hábito alimentar.

O peso das tradições nos hábitos alimentares é um aspecto relevante na alimentação dos marroquinos, e a influência religiosa é explícita, pois a maioria deles é muçulmana e busca na Lei Islâmica (Shari'a) a fundamentação para condutas do cotidiano - alimentação, vestuário, casamento. O Alcorão contém muitos versículos que aconselham sobre alimentação saudável, relacionados à interligação entre a saúde física e a espiritual. Comer somente alimentos bons e puros geralmente é lembrar-se de Deus e evitar Satanás (Stacey, 2015). Além de especificar proibições e períodos de jejum (Ramadan), a religião islâmica também dita como devem ser produzidos os alimentos.

Durante a viagem, percebemos que o alto consumo de chá verde quente e adoçado é outro aspecto marcante na cultura alimentar marroquina, sendo bebido acompanhando ou não de uma refeição, e costuma ser oferecido como cortesia em restaurantes. Desde o século XIX, o chá tornou-se bebida essencial das populações da África do Norte, impulsionada pelos negociantes ingleses que transportavam o chá produzido na China (Lemps, 2015). Hoje, juntamente com os chineses, os árabes são os maiores consumidores de chá do mundo. Seu consumo elevado entre os muçulmanos pode estar associado à proibição do consumo de bebidas alcoólicas (Gracindo, 2013).

Entretanto, o chá é uma atividade social exclusiva dos homens, que costumam lotar bares para conversar e beber chá, sempre sem a presença feminina. Ainda, além do seu consumo em locais públicos ser majoritariamente masculino, o preparo do chá é tradicionalmente um privilégio desse gênero (Gracindo, 2013). Historicamente, essa diferenciação entre os gêneros tem limitado as mulheres a casa, aos cuidados dos filhos 
e à responsabilidade pelo bom funcionamento da mesma, enquanto que os homens assumem papéis na política e nos governos, na religião e na esfera econômica (Keddie; Baron, 1993).

Em se tratando da mundialização dos mercados e sua relação com novos hábitos alimentares, nos pareceu que isso ainda não ocorreu de forma significativa no Marrocos. A maioria das grandes cidades marroquinas possuem uma medina: parte antiga da cidade cercada por fortificações, que foram construídas como proteção contra as invasões. Hoje, as medinas são conhecidas como o centro histórico, pois se encontram cercadas pela parte nova da cidade.

Caminhando pelas estreitas ruelas e becos que as compõem, percebemos que as medinas são, de certa forma, organizadas, havendo uma divisão entre as áreas para o comércio, com mercados; áreas residencial e de hospedagem e áreas onde se encontram os artesãos. Assim, havia muitas tendas especializadas, onde era possível comprar especiarias e frutas secas, frutas e verduras frescas, carnes, doces à base de nozes e amêndoas, roupas, sapatos e acessórios em couro de cabra. Praticamente, todos os alimentos eram vendidos a granel, não havendo espaço significativo para produtos industrializados.

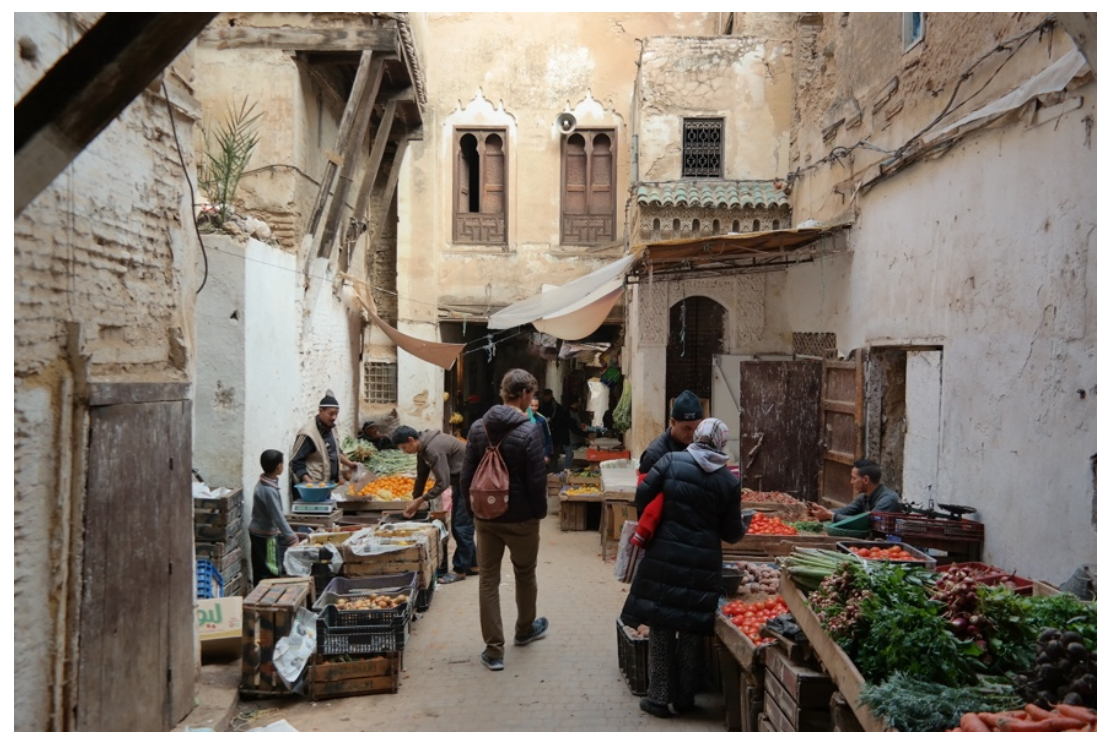

Figura 9. Venda de alimentos frescos na medina de Fès.

Fonte: Acervo pessoal (2016). 


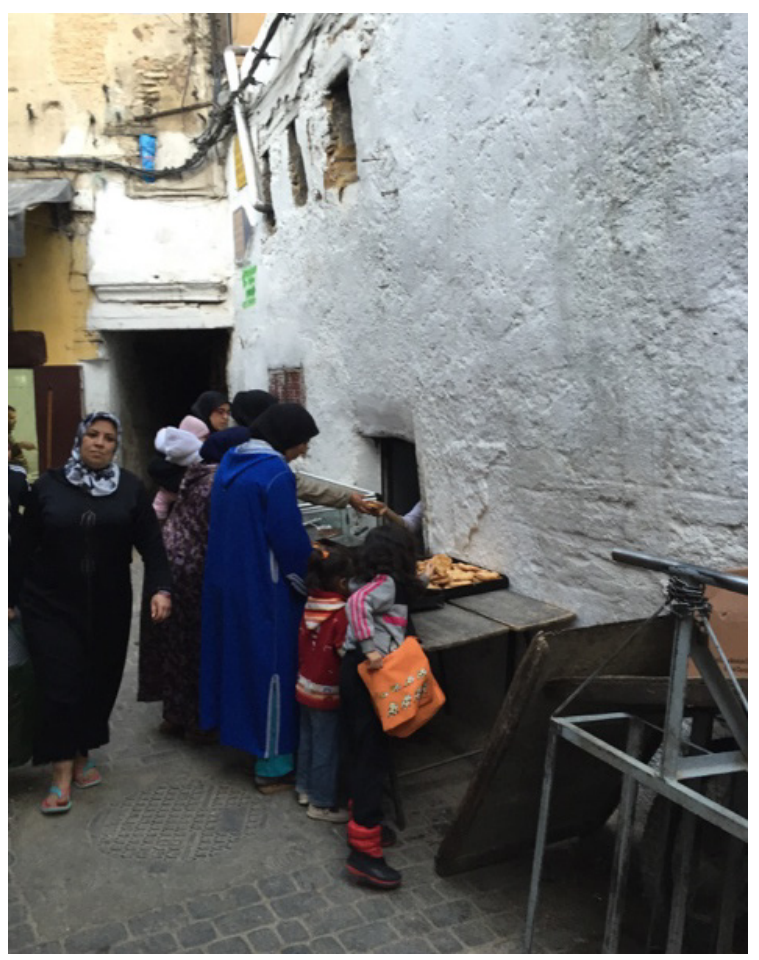

Figura 10. Venda de pães em postigo na medina de Fès.

Fonte: Acervo pessoal (2016).

$\mathrm{O}$ fato de termos vivenciado a cultura marroquina foi rico, mas inquietante. Raros foram os momentos em que eu me sentia confortável em locais públicos não turísticos, principalmente em bares e restaurantes de pequenas vilas, sendo a única mulher presente. Diariamente, sentia-me coagida a usar calça, blusa com manga e cabelos presos. A comunicação com os moradores locais também era difícil, porque minha presença era ignorada e não me dirigiam a palavra. Em muitas esferas, a distinção entre gêneros ainda é muito presente, mesmo na vivência da alteridade/com quem está disposto a conhecer e viver mais a cultura marroquina.

\section{Comer em Portugal: um olhar sobre a convergência e a fusão das culinárias indígena, africana e portuguesa}

Em Portugal, frequentando supermercados e padarias, logo percebemos uma semelhança com os produtos encontrados no Brasil, principalmente no que diz respeito aos doces. Nos restaurantes, comemos desde pratos característicos de Portugal, como a sardinha e o bacalhau à bras, quanto pratos comuns aos brasileiros, como estrogonofe de carne, polenta e broa de milho. Essas semelhanças e o reconhecimento de alimentos que também fazem parte da identidade culinária brasileira geraram um sentimento de 
pertencimento ao local, remetendo a um ambiente familiar, fazendo-nos sentir mais íntimos de Portugal.

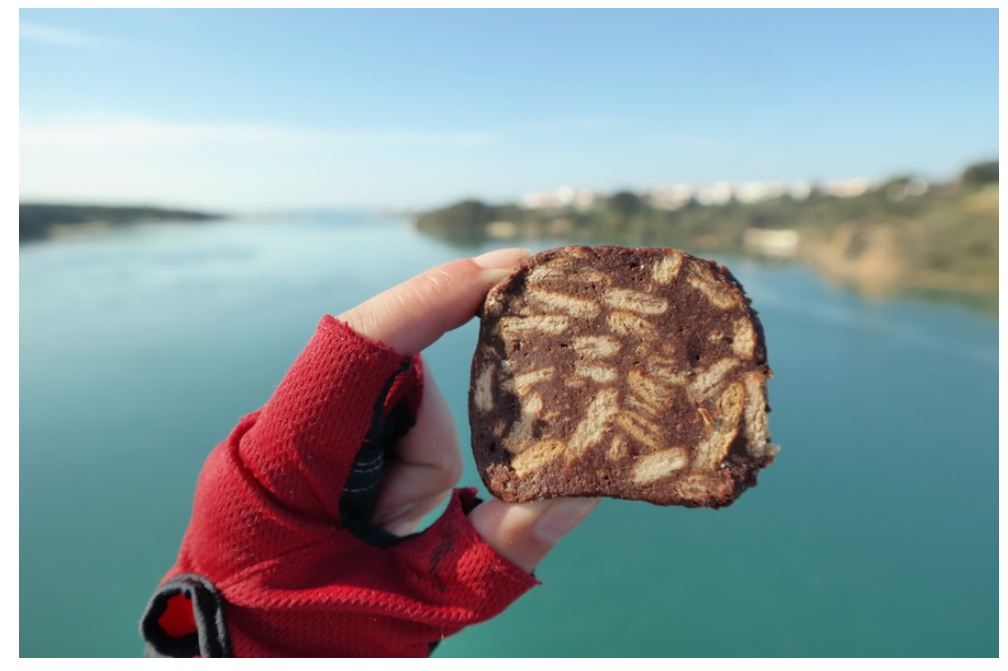

Figura 11. Salame de chocolate português.

Fonte: Acervo pessoal (2016).

A cozinha portuguesa, mesmo já consolidada, transformou-se e recriou-se ao entrar em contato com novos ingredientes e alimentos descobertos durante as grandes navegações. Mesmo a culinária brasileira tendo sido construída com a influência desses colonizadores, muitos alimentos próprios ao Continente Americano fizeram o caminho inverso, sendo introduzidos na Europa e provocando transformações em sistemas alimentares já existentes (Maciel, 2004). A batata, a pimenta e o milho foram os três primeiros produtos da América a atravessarem o Atlântico e se expandirem pelo mundo (Cascudo, 2011).

A cozinha brasileira, por sua vez, é considerada o resultado de um processo histórico que incluiu e excluiu elementos da cultura alimentar indígena: mandioca, amendoim e milho; africana: azeite de dendê e melancia, e portuguesa: açúcar, ovos e leite (Rrodrigues, 2016). Assim, tem-se a cozinha brasileira como o resultado da junção de elementos diversos. Entretanto, em seu artigo intitulado Uma cozinha à Brasileira, Maciel (2004) salienta a importância de olharmos de maneira mais ampla e crítica para o que seriam as "contribuições" desses três diferentes grupos sociais para a formação da cozinha brasileira.

O problema está na maneira como a diversidade é percebida e utilizada. Converter a participação dos povos fundadores e fundantes da nacionalidade em 'influências' 
ou 'contribuições', em suma, em 'vestígios', é uma ação redutora que ignora o processo histórico em que se deu essa participação, processo este que envolveu desigualdades, conflitos, discriminações e hierarquizações (MACIEL, 2004: 28).

É fundamental percebermos que as "contribuições" dos três diferentes grupos aconteceram em um contexto de grande hierarquia e conflitos, por se tratar de um período de colonização e de regime escravocrata.

O português colonizador instalou-se para ficar definitivamente nas novas terras, reproduzindo o seu ambiente familiar e trazendo consigo o costume da criação de animais, quintal e horta (Cascudo, 2011). Além dos novos verdes plantados nos solos da colônia brasileira para o consumo cotidiano, a principal ocupação foi a produção de cana-de-açúcar. Com o objetivo de explorar novas fontes de riqueza (além da extração de recursos naturais brasileiros) e manter a colônia brasileira ocupada com algo rentável, os portugueses colocaram em prática o que já dominavam desde o século XV nas ilhas do Atlântico (Ferlini, 1994).

Assim, o colonizador introduziu, no Brasil, a matéria-prima do açúcar, e as mãos das portuguesas apresentaram o seu uso na cozinha. Juntamente com o ovo da galinha, alimento até então não utilizado pelos negros e indígenas, e com a farinha de trigo, o doce português logo ganhou apreço.

O açúcar conquistou a todos, incluindo-se imediatamente na gustação coletiva. Farinha de mandioca com açúcar, união de dois produtos geograficamente distanciados nas origens, foi gulodice vulgar por todo o Brasil (Cascudo, 2011: 243).

De acordo com registros da época, a cozinha dos índios era considerada primitiva e rudimentar, mas apresentou e difundiu diversos gêneros alimentícios até então desconhecidos, e manteve diversos pratos à base de milho e mandioca, além de pratos compostos de farinha, carne assada pisada no pilão e peixe seco. As indígenas, por sua vez, fundamentais na cozinha brasileira: "foram as primeiras cozinheiras que o português dispôs, na ausência ou mesmo na proximidade da mulher legítima, a mestra inicial da cozinha brasileira" (Cascudo, 2011: 158). Assim, no início da cozinha colonial houve a atuação tanto da mulher portuguesa quanto da cunhã.

O colonizador já plantava e colhia, nas terras brasileiras, os temperos e alimentos que havia trazido de Portugal, de modo que a cunhã precisava aprender com a mulher branca como manejar esse mundo novo de alimentos (Cascudo, 2011). Ao mesmo tempo em que a cunhã conhecia esses alimentos, ela apresentava suas técnicas de preparar carnes e peixes assados na brasa. Ainda, a mão da cozinheira portuguesa 
deu mais valor às iguarias indígenas, fazendo o beiju mais fino e seco (Cascudo, 2011). Assim, alimentos exclusivos da fauna indígena foram então modificados pelas técnicas da tradição portuguesa, e o que não era da colônia brasileira e vinha de Portugal tornouse brasileiro pela continuidade do seu uso (Cascudo, 2011).

Posteriormente, Cascudo (2011) retrata uma concorrência entre as mucamas, criadas negras, e as cunhãs, e estas últimas foram sendo empurradas para o sertão, seguindo os índios de sua tribo que não haviam se adaptado às rotinas açucareiras. A negra caiu como uma avalanche, afastando a cunhã que desaparecia. A mucama encheu as cozinhas senhoriais, sendo discípula em ambas as fórmulas do sabor culinário e sexual solicitadas (Cascudo, 2011).

O desaparecimento da cunhã não lhe retira o direito inegável de ter sido a primeira cozinheira histórica, revelação fecunda da terra virgem, mãe do primeiro brasileiro (Cascudo, 2011: 160).

Desde a primeira metade do século XVI, muitos africanos de distintas origens embarcaram como escravos para o Brasil. Os africanos eram generalizados como "guinés", mas sabe-se que populações africanas distintas entre si vieram para o Brasil para os engenhos de açúcar, mineração e lavouras brasileiras, cada qual com suas especificações culturais (Cascudo, 2011). Sem distinguir as diferentes populações africanas, as “contribuições" da culinária africana são muito citadas em livros.

\footnotetext{
A influência negra na alimentação foi marcante. O uso do quiabo, da banana, a grande variedade de formas de preparo de peixes e de aves, o vatapá, o caruru, a feijoada, o acarajé, o sabor forte do dendê e da pimenta, a utilização do coco testemunham a presença dos escravos na cozinha colonial, trazendo até nós o tempero e a criatividade do africano (FERLINI, 1994: 45).
}

Entretanto, é importante que essas leituras sejam feitas de maneira mais crítica, desromantizando a contribuição da cozinha africana pelo negro escravizado. Segundo Maciel (2004), esses não podiam trazer bagagem material, sendo os elementos tradicionais da cozinha africana trazidos por comerciantes que faziam a rota de comércio de mercadorias e escravos entre Portugal, Brasil e África. Dessa forma, os portugueses foram agentes distribuidores de espécies alimentares, trazendo diversas sementes e raízes orientais e africanas para o Brasil e disseminando outros gêneros alimentares brasileiros (Cascudo, 2011). Assim, valoriza-se que, mais do que os ingredientes propriamente ditos, o principal elemento trazido pelos escravos africanos 
foi a bagagem cultural, que abrange os hábitos alimentares, com suas técnicas, regras e significados (Maciel, 2004).

Assim, após o contato com a comida portuguesa e do olhar mais atento para nossa culinária brasileira apreendemos algumas convergências e fusões entre as culinárias indígena, africana e portuguesa. A partir desses elementos é possível analisar alguns aspectos da cozinha brasileira, em um contexto mais social, apontando algumas singularidades para uma leitura mais crítica sobre a formação da mesma e, consequentemente, da nossa sociedade.

\section{Considerações finais}

Viajar de bicicleta e experienciar a cultura do outro em sua totalidade, vivenciando práticas e costumes singulares de cada uma, foi transformador tanto do ponto de vista alimentar quanto social e profissional. Pensar a palavra cultura no seu sentido antropológico como fornecedora de conhecimentos, valores e símbolos que orientam e guiam as vidas humanas, possibilitou um redescobrimento da nossa própria identidade. A comensalidade compartilhada, especialmente com os franceses; a flexibilidade e a tolerância exercitadas no cotidiano do Marrocos; os questionamentos e as críticas sobre herança alimentar feitos especialmente em Portugal, foram algumas das experiências que abriram portas para enxergarmos possibilidades de estudos na temática da alimentação.

O exercício de estarmos atentos às situações das vivências em cada lugar e seus contextos, com tantas pessoas tão distintas culturalmente entre si, foi intenso. Contudo, foi esse olhar atento que possibilitou os registros de viagem e, sucessivamente, o estudo e a análise do fenômeno alimentar alheio. Foi fascinante e desafiador estudar a alimentação além do campo biológico, atentando para as suas dimensões socioculturais. Distinguir os limites e possibilidades das diferentes áreas do conhecimento, buscando quebrar e extrapolar a segmentação que temos entre as ciências biológicas e humanas mostrou-se custoso, pois as leituras técnicas e socioantropológicas contrastam bastante.

À luz das percepções levantadas, defendemos a relevância de a Nutrição ter um enfoque mais socioantropológico em suas práticas, estudos e relação com as pessoas. Não somos apenas físicos e biológicos para lidar com os alimentos apenas como suprimento de nutrientes; também somos sociais e culturais. Assim, ambas as ciências biológicas e humanas devem ser consideradas e abordadas na formação, atuação e 
intervenção do profissional da área de Nutrição, o qual influencia os hábitos alimentares dos indivíduos.

\section{REFERÊNCIAS}

BARBOSA, Lívia. Feijão com arroz e arroz com feijão: o Brasil no prato dos brasileiros. Horizontes Antropológicos, Porto Alegre, v.13, n. 28, p. 87-116, dez 2007.

BESSIS, Sophie. Mille et une bouches: cuisines et identités culturelles. Paris: Autrement, 1995.

CANESQUI, Ana M.; GARCIA, Rosa.W.D. Antropologia e Nutrição: um diálogo possivel. Rio de Janeiro: Fiocruz, 2005.

CASCUDO, Luís C. História da Alimentação no Brasil. 4. ed. São Paulo: Global, 2011.

CONTRERAS, Jesús; GRACIA, Mabel. Alimentação, sociedade e cultura. Rio de Janeiro: Editora Fiocruz, 2011.

CONTRERAS, Jesús. Patrimônio e Globalização: o caso das culturas alimentares. In: CANESQUI, Ana M.; GARCIA, Rosa.W.D. Antropologia e Nutrição: um diálogo possivel. Rio de Janeiro: Fiocruz, 2005.

FEATHERSTONE, Mike. Cultura de consumo e pós-modernismo. São Paulo: Studio Nobel, 1995.

FERLINI, Vera L. A. A Civilização do Açúcar Séculos XVI a XVIII. 8. ed. São Paulo: Brasiliense, 1994.

FISCHLER, Claude; MASSON, Estelle. Comer: a alimentação de franceses, outros europeus e americanos. São Paulo: Editora Senac São Paulo, 2010.

FISCHLER, Claude. El (h)omnívoro: el gusto, la cocina y el cuerpo. Barcelona: Anagrama, 1995.

FLANDRIN, Jean L.; MONTANARI, Massimo. História da alimentação. 8. ed. São Paulo: Estação Liberdade, 2015.

GEERTZ, Clifford. Nova Luz sobre a Antropologia. Rio de Janeiro: Jorge Zahar, 2001.

GRACINDO, Ina. Viagem ao mundo do chá. Rio de Janeiro: Casa da Palavra, 2013.

KEDDIE, Nikki R; BARON, Beth. Women in the Middle Eastern History. Yale University Press, 1993. 
LAPLANTINE, Fraçois. Aprender Antropologia. 15. ed. São Paulo: Brasiliense, 2003.

LEMPS, Alain H. As bebidas coloniais e a rápida expansão do açúcar. In:

FLANDRIN, Jean. L.; MONTANARI, Massimo. História da alimentação. 8. ed. São

Paulo: Estação Liberdade, 2015.

LIMA, Romilda S.; NETO, José A. F.; FARIAS, Rita C. P. Alimentação, comida e cultura: o exercício da comensalidade. Demetra: Alimentação, Nutrição e Saúde, Rio de Janeiro, v. 10, n. 3, p. 507-522, jul. 2015. Disponível em: <http://www.epublicacoes.uerj.br/index.php/demetra/article/view/16072>. Acesso em: 05 abr. 2018.

MACIEL, Maria E. Cultura e Alimentação ou o que têm a ver os macaquinhos de Koshima com Brillat-Savarin? Horizontes Antropológicos, Porto Alegre, v. 7, n. 16, p. 145-156, dez. 2001

MACIEL, Maria E. Uma cozinha à brasileira. Estudos Históricos, Rio de Janeiro, v. 1, n. 33, p. 25-39, jun. 2004

MICHEL, Franck. Désirs d'ailleurs: essai d'anthropologie des voyages. Paris: Armand Colin, 2000.

MONTANARI, Massimo. Comida como cultura. São Paulo: Editora Senac São Paulo, 2008.

OLDWAYS. Mediterranean Diet Pyramid: A contemporary approch to delicious, healthy eating, 2009. Disponível em:

$<$ https://oldwayspt.org/system/files/atoms/files/OW_MedPyramid_HiResLetter.pdf $>$. Acesso em: 28 mai. 2018. Oldways Preservation and Exchange Trust.

ORTIGOZA, Silvia A. G. Mudanças e persistências dos hábitos alimentares no Brasil e seus impactos no espaço urbano. In: Encontro de Geógrafos da América Latinam 8., Santiago, 2001. Anais... Santiago, 2001. Disponível em:

$<\mathrm{http}$ ://observatoriogeograficoamericalatina.org.mx/egal8/Geografiasocioeconomica/Ge ografiaurbana/15.pdf $>$. Acesso em: 5 abr. 2018.

PEIXOTO, Nelson B. Cenários em ruínas. São Paulo: Brasiliense, 1987

PEYER, Hans C. Os primórdios da hotelaria na Europa. In: FLANDRIN, Jean. L.; MONTANARI, Massimo. História da alimentação. 8. ed. São Paulo: Estação Liberdade, 2015.

POULAIN, Jean P. Sociologias da Alimentação: os comedores e o espaço social alimentar. Florianópolis: Editora da UFSC, 2004.

RODRIGUES, Carlos E. A influência da alimentação em quem somos. Diálogos e Saberes, Mandaguari, v.12, n. 1, p. 9-24, 2016

RODRIGUES, Heloísa A. F. Alimentação como fonte de sociabilidade e de hospitalidade. Sinais: Revista Eletrônica Ciências Sociais, Vitória, v. 1, n. 12, p. 85100, dez. 2012. 
ROSENBERGER, Bernard. A cozinha árabe e sua contribuição à cozinha europeia. In: FLANDRIN, Jean. L.; MONTANARI, Massimo. História da alimentação. 8. ed. São Paulo: Estação Liberdade, 2015.

STACEY, Aisha. Saúde no Islã: Dieta e Nutrição. Islam Religion, 2015. Disponível em: <https://www.islamreligion.com/pt/articles/1892/saude-no-isla-parte-3-de-4/>. Acesso em: 22 mai. 2018

UNESCO, UNITED NATION EDUCATIONAL, SCIENTIFIC AND CULTURAL ORGANIZATION. Decision of the Intergovernmental Committee: 8.COM 8.10. Baku, 2013. Disponível em: $<$ https://ich.unesco.org/en/décisions/8.COM/8.10>. Acesso em: 7 mai. 2018.

ZIMERMAN, David E. Etimologia de termos psicanalíticos. Porto Alegre: Artmed, 2012.

ZUIN, Luís F. S.; ZUIN, Poliana B. Alimentação é cultura: aspectos históricos e culturais que envolvem a alimentação e o ato de se alimentar. Nutrire: Revista da Sociedade Brasileira de Alimentação e Nutrição, São Paulo, v. 34, n. 1, p. 225-241, abr. 2009.

Recebido 10/10/2019

Aprovado 11/12/2019 